\title{
Ship emissions from Australian ports
}

\author{
M. Davies \\ Air Quality and Greenhouse Gas Emissions, SKM, Newcastle, UK
}

\begin{abstract}
The focus of attention from regulatory bodies in Australia with respect to air pollution emissions is for land-based industries and activities; as such, little attention has been paid to emissions from ships operating in Australian ports. Emissions standards for ships in general are not included in Australian legislation, although the international standard, MARPOL 73/78, sets limits on emissions of oxides of nitrogen and sulphur. There is an ongoing need to improve and upgrade port facilities, including the capacity of ports to accommodate more ships. In Sydney, for example, there is a high demand for an increase in container and passenger ships to meet the needs of the local market. The effective management of the air quality impacts of these shipping activities is, however, difficult as regulators and port operators have little or no control over the ships that access their ports. In addition regulatory attempts to control emissions in one region may reduce the competitiveness of ports in that region, which ships diverting to other regions to avoid the impact of emission regulation. An assessment of environmental impacts forms an integral part of the approvals process for new port and port upgrade projects. Air quality impacts from ship emissions have not historically been an important part of these assessments. Recent investigations, however, suggest that emissions from these ships may potentially affect local and regional air quality. Two Sydney studies investigated the emissions from ships berthing in busy city ports with nearby sensitive receivers. Emissions were estimated from engine sizes and operating regimes and the emission estimation technique provided by the Australian Government for national pollutant reporting purposes. Dispersion modelling was conducted using both the AUSPLUME and CALPUFF models to determine ground-level concentrations of fine particulate matter $\left(\mathrm{PM}_{10}\right)$, nitrogen dioxide $\left(\mathrm{NO}_{2}\right)$ and sulphur dioxide $\left(\mathrm{SO}_{2}\right)$. The feasibility of air quality management measures including Emission Control Areas (ECAs) and shore power for ships is investigated. The studies highlight the importance of
\end{abstract}


assessment of pollutants from large ships, which may affect short-term air quality in areas adjacent to berths. Such assessments are particularly important at the planning phase of developments, and require the establishment of representative emissions inventories and emission estimation techniques.

Keywords: MARPOL, Emission Control Areas (ECAs), AUSPLUME, CALPUFF.

\section{Introduction}

The air quality impacts of ship emissions in Australia have not traditionally been assessed in any formal or quantitative way. Rather, assessments have generally focused on land-based emissions sources associated with these developments. This is despite emissions of oxides sulphur $\left(\mathrm{SO}_{\mathrm{X}}\right)$ from shipping representing about $60 \%$ of global transport $\mathrm{SO}_{\mathrm{X}}$ emissions, and emissions of oxides of nitrogen $\left(\mathrm{NO}_{\mathrm{X}}\right)$ from shipping representing about $15 \%$ of all global anthropogenic $\mathrm{NO}_{\mathrm{X}}$ emissions (Dalsoren [2]). This paper presents an overview of ship emission quantities in Australian ports, and national and international ship emission regulations. Additionally it presents two case studies being quantitative assessment conducted for port developments in NSW, Australia. The air quality impacts associated with ships at berth were assessed, including dispersion modelling based on emissions estimates. Issues identified by the studies included the lack of regulatory emission limits on ship in Australia; a lack of validated emissions data from ships to use in such assessments; and potential adverse effects on air quality that may occur at sensitive receptor locations close to port facilities.

\section{Ship emission estimates in Australian ports}

A NSW Office of Environment and Heritage (OEH) commissioned study titled Potential Measures for Air Emissions from NSW Ports (Holmes [3]) summarised port emissions from the Sydney GMR as outlined in Table 1.

Table 1: Sydney GMR port emissions.

\begin{tabular}{|l|c|c|c|c|c|}
\hline \multirow{2}{*}{ Source of emissions } & \multicolumn{5}{|c|}{ Emissions (tonnes/annum) } \\
\cline { 2 - 6 } & $\mathrm{PM}_{10}$ & $\mathrm{PM}_{2.5}$ & $\mathrm{NO}_{\mathrm{X}}$ & $\mathrm{VOC}$ & $\mathrm{SO}_{2}$ \\
\hline Shipping & 892 & 820 & 9688 & 198 & 7187 \\
\hline Cargo handling & 59 & 58 & 1082 & 97 & 0.5 \\
\hline Diesel rail freight & 156 & 151 & 8154 & 317 & 9 \\
\hline Diesel road freight & 0.5 & 0.5 & 19 & 1 & 0.1 \\
\hline GMR total port emission & 1108 & 1030 & 18943 & 516 & 7197 \\
\hline GMR total emission & 75128 & 30499 & 292054 & 171067 & 301863 \\
\hline
\end{tabular}


In the Australian context ship emissions from the two commercial ports within the Sydney Greater Metropolitan Region (GMR) which include Port Botany, Glebe Island / White Bay and then Newcastle and Port Kembla ports, make up about 30 to $40 \%$ of annual in port ship emissions.

There is some uncertainty associated with this estimate as historically there has not been a clear methodology for assessing ship emission estimates, with common problems being setting boundaries for ship emission estimates while in port and travelling to and from berthing areas, accurate ship fleet information including engine type and size as well as fuel specification, and emission estimate techniques. Some of these issues are starting to be overcome with recent studies by Goldsworthy and Goldsworthy [4] who have developed a detailed ship exhaust emissions inventory (2010/11) using a shipping Automatic Identification System (AIS) and mapping of spatially distributed emissions.

\section{Ship emissions regulation}

One of the first stages of air quality impact assessments in NSW is to determine whether emission rates from plant and equipment meet statutory limits. Australia currently has no specific regulatory limits pertaining to the emissions from ships. International regulations are discussed below.

\subsection{MARPOL 73/78}

The International Convention for the Prevention of Pollution from Ships 1973/1978 (MARPOL) [1] was designed to minimise pollution of the seas, including dumping, oil and exhaust pollution. Exhaust emission limits of $\mathrm{SO}_{\mathrm{X}}$ and $\mathrm{NO}_{2}$ specified in Annex IV of MARPOL came into force in 2005. More stringent emissions requirements were specified through the 2008 Amendments to MARPOL Annex VI, as per Table 2.

\subsection{Other standards}

Emission limits other than MARPOL are used in specific regions with examples including:

- 2010 fuel sulphur limit of $0.1 \%$ at berth in the European Union;

- 2012 distillate fuel, fuel sulphur limit of $0.1 \%$ in Californian Waters.

In some regions emissions are also controlled by taxes and incentives with examples including Norwegian $\mathrm{NO}_{\mathrm{X}}$ tax and differentiated harbour dues in Sweden for $\mathrm{NO}_{\mathrm{X}}$ and fuel sulphur and in Vancouver for fuel sulphur. 
Table 2: $\quad$ MARPOL standards.

\begin{tabular}{|c|c|}
\hline Date & MARPOL standard \\
\hline 2005 & $\begin{array}{l}\text { Tier } 1 \mathrm{NO}_{\mathrm{x}} \text { for new engines post } 2000 \text {. Tier } 1= \\
\quad-\quad 17.0 \mathrm{~g} / \mathrm{kWh} \text { when } \mathrm{n} \text { is less than } 130 \mathrm{rpm} \text {; } \\
\text { - } \quad 45 \mathrm{x} \mathrm{n}^{(-0.2)} \mathrm{g} / \mathrm{kWh} \text { when } \mathrm{n} \text { is } 130 \text { or more but less than } 2,000 \mathrm{rpm} \text {; } \\
\text { - } \quad 9.8 \mathrm{~g} / \mathrm{kWh} \text { when } \mathrm{n} \text { is } 2,000 \mathrm{rpm} \text { or more. }\end{array}$ \\
\hline 2010 & Emission Control Area (ECA) fuel sulphur limit of $1 \%$ \\
\hline 2011 & $\begin{aligned} \text { Tier } 2 \mathrm{NO}_{\mathrm{x}} \text { for new engines post } 2011 . \text { Tier } 2= \\
\text { - } \quad 14.4 \mathrm{~g} / \mathrm{kWh} \text { when } \mathrm{n} \text { is less than } 130 \mathrm{rpm} \text {; } \\
\text { - } \quad 44 \mathrm{x} \mathrm{n}^{(-0.2)} \mathrm{g} / \mathrm{kWh} \text { when } \mathrm{n} \text { is } 130 \text { or more but less than } 2,000 \mathrm{rpm} \text {; } \\
\text { - } \quad 7.7 \mathrm{~g} / \mathrm{kWh} \text { when } \mathrm{n} \text { is } 2,000 \mathrm{rpm} \text { or more. }\end{aligned}$ \\
\hline 2012 & Global fuel sulphur $3.5 \%$ \\
\hline 2015 & Emission Control Area (ECA) fuel sulphur limit of $0.1 \%$ \\
\hline 2016 & 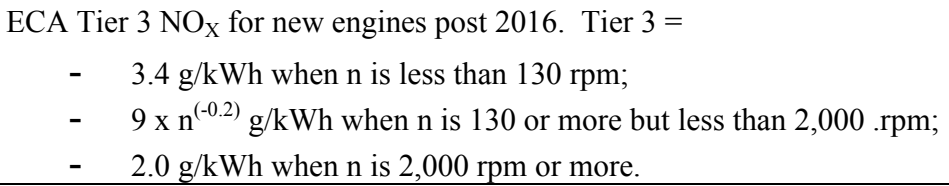 \\
\hline 2020 & Global fuel sulphur $0.5 \%$ \\
\hline
\end{tabular}

\section{Project case studies}

This section provides an overview of two Australian shipping air quality assessments in Sydney, NSW.

\subsection{Case study 1: Port Botany Expansion}

The Port Botany Expansion project in Sydney which is under construction by Sydney Ports Corporation (SPC) [5] will increase the capacity of the port from 1.62 million Transport Equivalent Units (TEUs) or containers in 2007 to over 3 million TEUs in 2020. Features of the expansion include:

- $\quad 1,850$ metres of additional wharf face for five extra shipping berths;

- 60 hectares of reclaimed terminal land;

- deep water berths with depths of up to 16.5 metres;

- dredging of approximately 7.8 million cubic metres of fill material to create shipping channels and berth boxes;

- dedicated road access to the new terminal area;

- additional rail sidings to provide rail access to the new terminal area; and

- additional tug berths and facilities. 
Figure 1 shows a layout of the existing port and the expansion project, which is now under construction. Sensitive receptors (neighbouring residential areas) are located more than $500 \mathrm{~m}$ from most of the berths modelled.

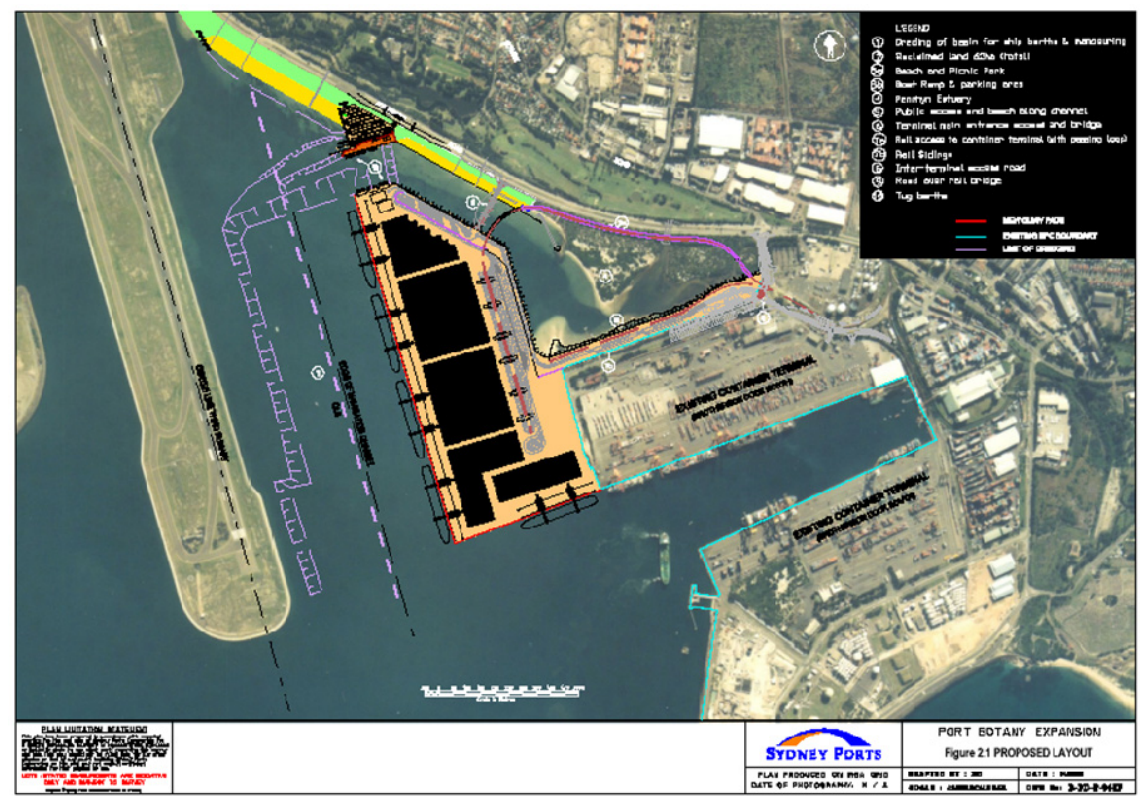

Figure 1: Port Botany expansion.

\subsection{Case study 2: White Bay Passenger Terminal}

Sydney Ports Corporation (SPC) are developing a Cruise Passenger Terminal (CPT) within the Glebe Island and White Bay Port Precinct on the Balmain Peninsula [6].

Approximately 170 ships per year would be expected to berth at the proposed CPT, with most ship visits having a turnaround time of less than 12 hours. Figure 2 provides an overview of the proposed development including residential development within $50 \mathrm{~m}$ of the CPT.

As relevant the proposed CPT will include:

- Refurbishment of two existing wharfs namely Wharf 4 and Wharf 5 for berthing of cruise ships; and

- Construction of a new purpose-built cruise terminal building. 


\section{Air quality assessment}

\subsection{Ship emissions estimation}

A literature review failed to locate any results of stack emission testing relating to ships that could be utilised for dispersion modelling purposes. As such, the National Pollutant Inventory (NPI) Emission Estimation Technique Manual for Maritime Operations [7], developed by the Australian government for pollution reporting purposes, was the only source of usable emission factors for these assessments.

The NPI Manual specifies ship engine emission factors for a range of pollutants, including $\mathrm{NO}_{\mathrm{X}}, \mathrm{SO}_{2}$ and $\mathrm{PM}_{10}$, for ships at berth that vary according to the type of fuel used.

Typical emission factors are as per Table 3.

Table 3: $\quad$ Ship emission factors.

\begin{tabular}{|c|c|}
\hline Substance & $\begin{array}{c}\text { Auxiliary Engine Emission Factors } \\
(\mathbf{k g} / \mathbf{k W h})\end{array}$ \\
\hline $\mathrm{NO}_{\mathrm{X}}$ & 0.0145 \\
\hline $\mathrm{PM}_{10}$ & 0.001 \\
\hline $\mathrm{SO}_{2}$ & 0.0097 \\
\hline
\end{tabular}

*Emission factors may vary for weighted average fuel burn (Table 7 of NPI EETM for Maritime Operations Version 2.0) - to be used when fuel type unknown.

The emission rates of $\mathrm{NO}_{\mathrm{X}}$ and $\mathrm{SO}_{2}$ from tradition medium and slow speed ship engines are very high when compared with similarly sized combustion appliances used for land-based applications, such as reciprocating diesel engines or gas turbines. The high $\mathrm{NO}_{\mathrm{X}}$ emissions result from high flame and combustion temperatures and inefficient air/fuel mixing ratios resulting in high "thermal $\mathrm{NO}_{\mathrm{X}}$ ". The high $\mathrm{SO}_{2}$ high emissions result from the relatively high sulphur content of marine fuels (up to 3.5\%) compared to Australian diesel fuel (which is now limited to $10 \mathrm{ppm}$, or $0.001 \%$ ). Both issues result from a lack of stringent emission regulations for ships both internationally and in Australia.

The use of these emission factors for dispersion modelling purposes is problematic. Firstly, the NPI Manual suggests a nominal $600 \mathrm{~kW}$ auxiliary engine size to be used when estimating emissions at berth for NPI reporting purposes. As actual engine sizes can be much larger than this nominal size (exceeding $4000 \mathrm{~kW}$ for some container, coal and passenger ships), the use of emission factors more specific to larger engine sizes for impact assessment purposes will provide more representative results.

The IHS Register of Shipping (Fairplay) provides a large database of ships operating in international waters, including Australian Ports. (IHS Fairplay international maritime information provider (UK, USA and Singapore) providing information on ships, companies, ports and movements to marine 
companies around the world.) Information on engine type and size for individual vessels is available and this could facilitate more accurate emissions estimation than using the NPI default size of $600 \mathrm{~kW}$, but an assumption is being made that the emission factors provide for smaller engines are suitable for larger engines as well. Emission rates for these assessments were estimated using the NPI emission factors scaled according to engine size data obtained from the Lloyd's Register for representative ships.

\subsection{Pollutants and emission sources}

The environmental regulator (the NSW DECC) considered the key pollutants to be $\mathrm{NO}_{\mathrm{X}}, \mathrm{SO}_{2}$ and $\mathrm{PM}_{10}$ for both assessments. The primary emission sources were the main and auxiliary ship engines operating while the ships were at berth. In order to provide a conservative estimate of the potential air quality impacts associated with the development, the study assumed ships would be present at all berths, each operating auxiliary engines continuously. Main engines were assumed to be operating for 1 hour following berthing and 1 hour prior to departing port.

Additionally, and in the case of the Port Botany Expansion land-based emission sources, such as on-site truck and train emissions, and diesel-operated dockside equipment such as rubber tyre gantries, straddle carriers and reach stackers, were also included.

\subsection{Results of dispersion modelling}

Dispersion modelling using AUSPLUME and CALPUFF was conducted to assess pollutant levels from both the existing and expanded port operations for both peak and average operations.

\subsubsection{Port Botany Expansion}

In the case of the Port Botany Expansion no exceedances of the relevant impact assessment criteria were predicted, with ground level concentrations of $\mathrm{SO}_{2}$, $\mathrm{PM}_{10}$ and $\mathrm{NO}_{2}$ generally well below the relevant air quality criteria.

Figure 2 presents the results of AUSPLUME dispersion modelling of cumulative 1-hour NO2 impacts from the operation of the Port Botany expansion with ships of varying size from very large ships (> 7000 TEU) to smaller ships (2000 TEU) occupying each of the five new berths and operating a combination of main and auxiliary engines.

\subsubsection{White Bay CPT}

In the case of the White Bay CPT the results of the dispersion modelling also showed that the project is unlikely to cause exceedance of the assessment criteria for $\mathrm{NO}_{2}, \mathrm{PM}_{10}$ or $\mathrm{SO}_{2}$ at nearest sensitive receptors. In contrast to Port Botany however, given the short distance between the port development and sensitive residential areas (approximately $50 \mathrm{~m}$ ) it was noted there was only a small margin of safety in terms of maintaining air quality impacts, particularly at times of poor dispersion meteorology. 
In response to this it was recommended that detailed air quality management and monitoring plans be developed [8]. In particular continuous $\mathrm{SO}_{2}$ and $\mathrm{PM}_{10}$ monitoring is to be undertaken at locations surrounding the development to measure the effect of ship emissions on sensitive areas.

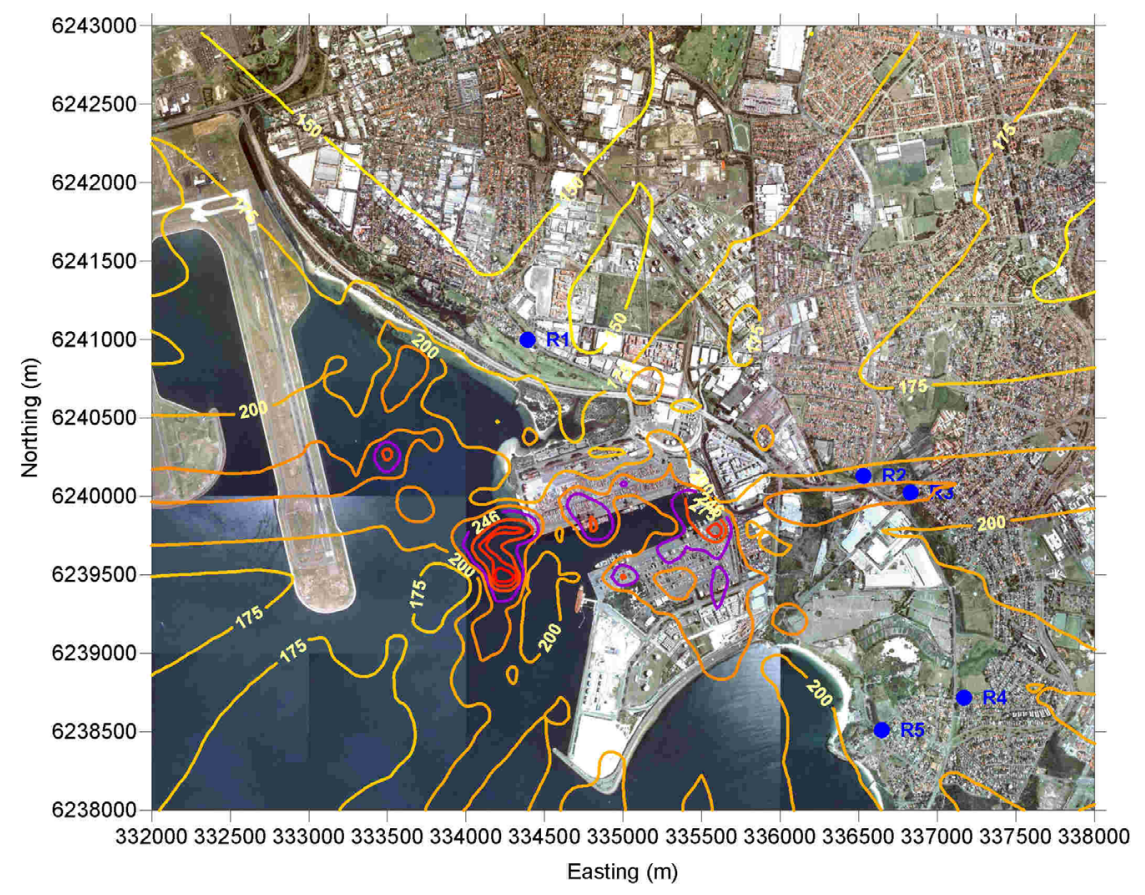

Figure 2: $\quad$ Port Botany 1-hour $\mathrm{NO}_{2}$ impacts $\left(\mu \mathrm{g} / \mathrm{m}^{3}\right)$.

\section{Future directions}

Further expansion of Australian ports is anticipated over the next 5-10 years, with major port upgrades either under way or planned in most Australian states.

It is considered prudent that regulators in all jurisdictions consider the air quality impact these port projects may have on both a local and regional scale. While some tightening of MARPOL regulations [1] will see a gradual reduction in ship emissions over time, it is unlikely that they will deliver significant emission reductions in the short-term to offset an increase in shipping activity within Australian ports.

\subsection{Actions for regulators}

As a first step, it is recommend that regulators require detailed assessments of the air quality impacts from ships to be conducted for port development projects, particularly those that result in increases in shipping activity. These assessments should include the development of representative air emissions inventories and 
air dispersion modelling to determine the effects of shipping activities on local and regional air quality.

Should these assessments identify potential air quality issues, consideration should be made to the designation of ECAs for coastal cities already experiencing air pollution problems. Such a move is currently proposed by the United States [9] and Canada, who propose to implement standards by 2016 to reduce the sulphur content in fuels by $96 \%$ and reduce emissions of particulate matter and NOX by $85 \%$ and $80 \%$ respectively in their designated ECAs.

In addition in the Australian context it is recommended regulators continue the work commenced in the NSW OEH preliminary study into ship emissions and potential management (PAE Holmes [3]) and this include:

- Revising existing NPI emission factors to better reflect the ship fleet accessing Australian ports;

- Confirm specific protocols for air quality assessments associated with new port or port expansion projects so these can be undertaken on a consistent basis;

- Forecast the expected reduction in shipping related emissions in Australian waters that will occur as a consequence of tightening MARPOL standards [1] and the time scales over which this will occur. It is noted that most new standards relate to new ship ships coming into service in the future, rather than standards relating to existing ships that may stay in service for considerably long periods.

- With regards to the tightening MARPOL standards [1] related to the sulphur content of fuel, assess specifically the impact these will have on lowering $\mathrm{PM}_{2.5}$ emissions and impacts, which is emerging as a significant pollutant in Australian communities.

\subsection{Opportunities for port operators}

Port operators typically have little control over the ships accessing their facilities, or their operational practices, such as fuel selection or engine operating regimes. In the absence of regulatory controls, efforts to reduce emissions can focus on assessing the feasibility of providing alternative energy sources for ships at berth (shore power) to reduce the use of auxiliary engines while at berth.

\subsubsection{Shore power}

Shore power or "cold-ironing" enables ships at dock to use shore-side electricity (normally from a local power grid through a substation at the port) to power electronic systems including fuel systems; loading and unloading activities; and to discontinue the use of its auxiliary engines. This switchover of electricity source eliminates air emissions associated with the use of auxiliary engines and shifts the air pollution emission burden to power generation facilities in the local grid which generally have much lower emission intensities and are located further away from sensitive receiver areas. 
It should be noted that shore power is expensive, estimated by the American Association of Port Authorities (AAPA) in a 2007 study [10] to be in the order of US \$3-7 million per berth for the required infrastructure upgrades and then it must be realised that the system may only be compatible with a small percentage of ships operating into and out of the port.

Internationally shore power has been considered in detail for the Euromax container terminal in Rotterdam, Holland and Shanghai Container Port in China. For the Euromax terminal development the recommendation was not to proceed with shore power at the time and while the Shanghai terminal has made provisioning for future ship connections to shore power there is no shore power facility at this time.

As ECA and associated emission regulations take hold it is anticipated that shore power will become more commercially viable, with current examples where the technology is rolling out including the ports of San Diego and Los Angeles.

\subsubsection{Other opportunities}

Dockside equipment emissions while only relatively minor in comparison to ship engines could be reduced by the installation of catalytic converters within diesel engines or the use of exhaust filtration devices, and replacing existing equipment with new engine technology using cleaner fuels, to minimise impacts.

\section{Conclusions}

Pollutant emissions from ships may significantly affect air quality, both at a local and regional level. While there are international guidelines relating to $\mathrm{NO}_{\mathrm{X}}$ emission levels and fuel sulphur content, there are currently no Australian regulations relating to ship emissions. Very limited data are currently available regarding pollutant emission rates from ships, particularly at berth, which is when their emissions are most likely to affect sensitive receptors. There is, however, some indication from the limited available data that ship emissions may potentially be of concern, particularly in areas where ship berths within port facilities are located close to residential areas.

It is recommended that regulators require detailed assessments of the air quality impacts associated with port development projects as part of the development approval processes. Such assessments should require accurate emissions estimations in order to provide the most benefit. While regulators are best placed to reduce the potential impacts of ship emissions through regulation and planning controls, port operators can also reduce emissions through activities under their control, such as considering opportunities for providing shore power for ships at berth and minimising their own land-based pollutant emissions.

\section{References}

[1] International Marine Organization, 1973/1978, International Convention for the Prevention of Pollution from Ships. 
[2] Dalsoren S.B., 2009 Update on Emissions and Environmental Impacts from the International Fleet of Ships.

[3] PAE Holmes, 2011, Potential Measures for Air Emissions from NSW Ports - Preliminary Study prepared for the NSW Office of Environment and Heritage.

[4] Laurie Goldsworthy and Brett Goldsworthy. Australian Maritime College, 2013, Ship Engine Emissions and Fuel Consumption in Australian waters including Ports.

[5] Sinclair Knight Merz, 2003, Port Botany Expansion Air Quality Assessment.

[6] Sinclair Knight Merz, 2010 White Bay Passenger Terminal Air Quality Assessment.

[7] Department of the Environment, Heritage and the Arts, 2008, National Pollutant Inventory Emission Estimation Technique Manual, for Maritime Operations.

[8] Sinclair Knight Merz, 2012 White Bay Passenger Terminal Air Quality Management Plan

[9] United States Environmental Protection Agency (USEPA), 2009, Proposal for Emission Control Area Designation for Geographic Control of the Emissions from Ships.

[10] American Association of Port Authorities (AAPA), 2007 Draft Use of Shore-Side Power for Ocean Going Vessels White Paper. 